\title{
Gaya manajemen konflik seminaris
}

\author{
Yoseph Pedhu \\ Universitas Katolik Indonesia Atma Jaya, Indonesia
}

\begin{tabular}{|c|c|}
\hline Article Info & ABSTRACT \\
\hline Article history: & Penelitian ini bertujuan untuk menelusuri gaya manajemen konflik para \\
\hline Received Des 22nd, 2019 & seminaris. Subjek penelitian berjumlah 44 orang yang merupakan para \\
\hline Revised Jan 30th, 2020 & seminaris yang sedang menjalani proses pembinaan untuk menjadi imam. \\
\hline Accepted Feb 18th, 2020 & $\begin{array}{l}\text { Data penelitian diperoleh dari skala penilaian manajemen konflik yang dibuat } \\
\text { peneliti, dan diuji dengan analisis deskriptif dengan rumus mean dan analisis } \\
\text { komparatif dengan rumus anova. Hasil penelitian menunjukkan bahwa para }\end{array}$ \\
\hline $\begin{array}{l}\text { Keyword: } \\
\text { Konflik } \\
\text { Manajemen } \\
\text { Gaya manajemen konflik }\end{array}$ & $\begin{array}{l}\text { seminaris lebih cenderung menggunakan gaya akomodasi dan jarang } \\
\text { memakai gaya kompetisi dalam mengelola konflik. Para seminaris perlu } \\
\text { mengembangkan gaya manajemen konflik yang cocok dalam menghadap } \\
\text { situasi konflik. }\end{array}$ \\
\hline
\end{tabular}

Gaya manajemen konflik

\begin{abstract}
Penelitian ini bertujuan untuk menelusuri gaya manajemen konflik para titian berjumlah 44 orang yang merupakan para Data penelitian diperoleh dari skala penilaian manajemen konflik yang dibuat peneliti, dan diuji dengan analisis deskriptif dengan rumus mean dan analisis komparatif dengan rumus anova. Hasil penelitian menunjukkan bahwa para situasi konflik.
\end{abstract}

\section{Corresponding Author:}

Yoseph Pedhu,

Universitas Katolik Atma Jaya

Email: osecp@yahoo.com
(C) 2020 The Authors. Published by Indonesian Institute for Counseling,

Education and Therapy (IICET). This is an open access article under the CC BY license (https://creativecommons.org/licenses/by/4.0/)

\section{Pendahuluan}

Konflik merupakan situasi yang wajar dalam relasi interpersonal dan semua orang pasti mengalaminya (Darling \& Walker, 2001; Desivilya \& Eizen, 2005; Kim, Kondo, \& Kim, 2007; Sutikno, 2008; Wijayati, 2009; Susanto \& Shih, 2010; Kashanah, 2014; Beitler, Machowski, Johnson, \& Zapf, 2016; Hasibuan, 2016; Khan, Hussainy, \& Iqbal, 2016). Markowich \& Farber (dalam Chan, Huang \& Ng, 2008) menggambarkan konflik sebagai proses alamiah yang terjadi antarindividu, dengan demikian konflik tidak dapat dihindari. Para ahli memandang bahwa konflik merupakan aspek alamiah dalam hubungan manusia sebagaimana yang ditekankan oleh Hocker dan Wilmot (dalam Tubbs \& Moss, 2008) bahwa konflik merupakan suatu proses alamiah yang melekat pada sifat semua hubungan dan dapat diatasi dengan pengelolaan yang konstruktif. Konflik yang dikelola dengan baik dapat digunakan untuk mempromosikan perubahanperubahan yang dikehendaki baik bagi individu maupun bagi komunitas.

Konflik terjadi akibat perselisihan yang timbul karena kebutuhan, dorongan, keinginan, atau tuntutan yang bertentangan. Persoalan yang muncul adalah bagaimana mengelola konflik, sehingga kebutuhan akan strategi pengelolaan konflik yang efektif sangat penting. Konflik yang dikelola dengan baik akan memperkuat hubungan kerja sama, meningkatkan kepercayaan, dan mempertinggi kreativitas dan produktivitas. Manajemen konflik yang kurang efektif akan memunculkan konflik baru berikutnya. Kegagalan dalam mengelola konflik tidak hanya menghambat pencapaian tujuan hidup bersama, tetapi juga merusak dinamika hubungan interpersonal. Konflik perlu dikelola dengan menggunakan strategi yang efektif agar tidak menghambat individu dalam meningkatkan kinerjanya (Wartini, 2015).

Penelitian tentang manajemen konflik telah dilakukan (Shih \& Susanto, 2010; Montes, Rodriguez, \& Serrano, 2012; Gross, Hogler, \& Henle, 2013; Hasibuan, 2016; Beitler, Machowski, Johnson, \& Zapf, 2016; Ghavifekr, Nair, \& Ibrahim, 2019; Lahana, Tsaras, Kalaitzidou, Galanis, Kaitelidou \& Sarafis, 2019). Penelitian Shih dan Susanto (2010) tentang gaya manajemen konflik, kecerdasan emosional dan kinerja kerja dalam organisasi publik menunjukkan bahwa kecerdasan emosional merupakan antesenden gaya manajemen konflik untuk gaya integrasi dan kompromi. Penelitian ini juga menyatakan bahwa gaya 
integrasi khususnya sebagai mediasi hubungan antara kecerdasan emosional dan kinerja. Penelitian Montes, Rodriguez, dan Serrano (2012) tentang pilihan afektif gaya manajemen konflik menunjukkan bahwa mood dan perasaan positif berkorelasi dengan preferensi atau kecenderungan responden untuk strategi manajemen konflik yang lebih kooperatif. Selain itu, Gross, Hogler, dan Henle (2013) melakukan penelitian tentang proses, individu, dan manajemen konflik dalam organisasi ditinjau dari pandanga teori Weber mengenai rasionalitas formal dan dan substantif bermanfaat bagi organisasi dan masyarakat dengan mempromosikan persepsi tentang perilaku perusahaan yang lebih positif.

Penelitian lain tentang manajemen konflik adalah penelitian Hasibuan (2016) mengenai strategi manajemen konflik. Hasilnya menunjukkan mahasiswa perantau dari luar Pulau Jawa lebih cenderung menggunakan conflict approach avoidance. Penelitian Beitler, Machowski, Johnson, dan Zapf (2016) menunjukkan bahwa karyawan yang berusia lebih tua mengalami sedikit stresor pelanggan. Karyawan yang berusia lebih tua dilaporkan lebih cenderung menggunakan gaya manajemen konflik konstruktif aktif lebih efektif. Sebaliknya, karyawan yang berusia lebih muda dilaporkan mendapatkan manfaat yang lebih sedikit dari penggunaan strategi manajemen dan menunjukkan tingkat kejenuhan yang lebih tinggi. Penelitian Ghavifekr, Nair, dan Ibrahim (2019) tentang praktik strategi manajemen konflik di sekolah menunjukkan bahwa komunikasi, otoritas, reward, sumberdaya, kepribadian, hubungan manusia, dan alokasi tugas merupakan faktor utama yang menyebabkan konflik. Hasil penelitian ini juga menyatakan bahwa pendekatan kolaborasi, akomodasi dan kompromi merupakan strategi utama yang digunakan oleh pemimpin sekolah, asisten senior, dan para guru ketika menghadapi situasi konflik. Penelitian Lahana, Tsaras, Kalaitzidou, Galanis, Kaitelidou dan Sarafis (2019) tentang manajemen konflik dalam sektor keperawatan publik menunjukkan bahwa gaya manajemen konflik yang secara umum digunakan adalah menghindar, diikuti oleh gaya kolaborasi, kompromi, kompetisi, mediasi, dan akomodasi. Kolaborasi merupakan gaya manajemen yang dipilih perawat yang lebih berpendidikan. Mayoritas perawat melaporkan bahwa mereka mengalami masalah dalam menentukan gaya manajemen konflik yang tepat sehingga dibutuhkan peningkatan pemahaman yang tepat tentang gaya-gaya manajemen konflik.

Boardman dan Horowits (dalam Mardianto, Koentjoro, \& Purnamanignsih, 2000) menekankan bahwa gaya manajemen konflik dipengaruhi oleh karakteristik kepribadian. Menurut Boardman dan Horowitz (dalam Mardianto, Koentjoro, \& Purnamanignsih, 2000) karakteristik kepribadian yang terutama berpengaruh terhadap gaya manajemen konflik individu adalah kecenderungan agresif, kebutuhan untuk mengontrol dan menguasai, orientasi koperatif atau kompetitif, kemampuan berempati, dan kemampuan untuk menemukan alternatif penyelesaian konflik. Sementara Collins dan Laursen (dalam Mardianto, Koentjoro, \& Purnamanignsih, 2000) memaparkan bahwa kemampuan manajemen banyak didukung oleh karakteristik-karakteristik seperti keterbukaan akan pendapat, hubungan yang hangat, serta kebiasaan untuk tidak memecahkan masalah secara sepihak.

Konflik sangat erat dalam kehidupan manusia. Hendricks (2006) berpendapat bahwa konflik adalah sesuatu yang tak terhindarkan. Menurut Aldag dan Stearns (dalam Wahyudi, 2011) konflik adalah ketidaksepahaman antara dua atau lebih individu atau kelompok sebagai akibat dari usaha kelompok lainnya yang mengganggu pencapaian tujuan. Luthans (2011) menggambarkan konflik sebagai ketidaksesuaian antara nilai atau tujuan antar anggota organisasi. Konflik dipandang sebagai perilaku yang mengganggu seseorang dalam mencapai tujuan yang ditetapkan.

Criblin (dalam Wahyudi, 2011) mengartikan manajemen konflik merupakan teknik yang dilakukan pemimpin organisasi untuk mengatur konflik dengan cara menentukan peraturan dasar dalam bersaing. Sementara menurut Wirawan (2013) manajemen konflik merupakan aktivitas untuk mengendalikan dan mengubah konflik demi menciptakan keluaran konflik yang menguntungkan. Manajemen konflik merupakan upaya untuk mengarahkan konflik destruktif menjadi konflik konstruktif sehingga menimbulkan dan mengembangkan kreativitas dan inovasi. Menurut Thomas (dalam Daft, 2010) terdapat lima gaya penanganan konflik, yaitu (1) bersaing, (2) menghindar, (3) berkompromi, (4) mengakomodasi, dan (5) berkolaborasi. Tidak ada gaya manajemen konflik yang efektif untuk semua situasi. Setiap individu diharapkan dapat memilih gaya yang cocok dengan karakter kepribadiannya untuk menangani konflik yang muncul dalam hidupnya. Gaya manajemen konflik yang tepat adalah gaya yang sesuai dengan kepribadian seseorang. Berhadapan dengan konflik interpersonal, individu diharapkan mampu menilai gaya manajemen konflik yang efektif. Hal-hal inilah yang mendasari peneliti untuk menelusuri gaya manajemen konflik para seminaris $\mathrm{X}$. 
Menurut Wikipedia (dalam http://id.wikipedia.org/wiki/konflik), kata konflik berasal dari kata kerja Latin configere yang berarti saling memukul. Secara sosiologis, konflik diartikan sebagai suatu proses sosial antara dua orang atau lebih dimana salah satu pihak berusaha menyingkirkan pihak lain dengan menghancurkannya atau membuatnya tidak berdaya. Konflik dipandang sebagai ketidaksesuaian antara keinginan, tujuan atau nilai-nilai antarindividu atau kelompok (Khanaki \& Hassanzadeh, 2010). Konflik merupakan suatu proses interaksi yang terjadi akibat adanya ketidaksesuaian antara dua pandangan atau perspektif yang berbeda yang berpengaruh atas pihak-pihak yang terlibat baik pengaruh positif maupun pengaruh negatif (Robbins \& Judge, 2013; Robbins, Judge, \& Breward, 2018).

Menurut Webster (dalam Pickering, 2001), konflik adalah pertentangan antara para pihak yang mengalami ketidakcocokan. Pemahaman ini sejalan dengan pandangan DuBrin (dalam Wijayati, 2009) yang menekan konflik sebagai pertentangan antar individu atau kelompok yang dapat meningkatkan kegagalan sebagai akibat saling menghalangi dalam pencapaian tujuan. Rahim (dalam Chan, Huang \& Ng, 2008) mengartikan konflik sebagai proses interaktif yang timbul karena perselisihan atau ketidaksesuaian dalam kelompok sosial. Daft (2010) mengartikan konflik sebagai interaksi yang bersifat bermusuhan dimana satu pihak berupaya menghambat pihak lain. Menurut Johnson (dalam Supratiknya, 1995), konflik adalah situasi dimana tindakan salah satu pihak berakibat mengganggu tindakan pihak lain. Sementara Barki dan Hartwick (dalam Chung-Yan \& Moeller, 2010) menjelaskan konflik interpersonal dengan mengacu pada pertentangan antarindividu sebagai akibat ketidakcocokan kepentingan atau tujuan. Dengan kata lain, konflik muncul karena adanya ketidaksesuaian dalam menghadapi situasi tertentu (Thomas \& Thomas, 2008). Pandangan ini senada dengan pemahaman Eisenhardt et al. (dalam Wartini, 2015) konflik yang menggambarkan konflik sebagai suatu proses interaksi yang terjadi akibat adanya ketidaksesuaian antara dua sudut pandang baik itu terjadi dalam ukuran organisasi, derajat spesialisasi yang diberikan kepada anggota organisasi, kejelasan jurisdiksi wilayah kerja, kecocokan antara tujuan anggota dengan tujuan organisasi, gaya kepemimpinan, dan sistem imbalan yang berpengaruh atas pihak-pihak yang terlibat.

Konflik muncul disebabkan adanya perbedaan dalam hal ide, nilai maupun perasaan antara dua atau lebih individu (Marquis \& Huston, 2012). Hal ini senada dengan pandangan Mullins (2005) yang menyatakan bahwa banyaknya perbedaan perilaku antara individu dapat mengakibatkan konflik dan setiap individu di dalam organisasi membutuhkan manajemen konflik yang baik agar konflik tidak merugikan diri individu dan organisasi. Pandangan serupa juga digarisbawahi oleh Hardjana (dalam Wijayati, 2009) bahwa konflik merupakan pertentangan antara dua orang/kelompok dimana perbuatan yang satu berlawanan dengan yang lainnya sehingga salah satu atau keduanya saling terganggu.

Berdasarkan pengertian beberapa ahli, disimpulkan bahwa konflik merupakan perselisihan yang muncul akibat kebutuhan atau tuntutan yang bertentangan antara dua pihak atau lebih. Konflik tidak bisa dihindari dalam interaksi dan hubungan antarpribadi. Konflik perlu dikelola dengan baik agar tujuan yang ditetapkan dapat tercapai.

Ivancevich, Konopaske \& Matteson (2007) mengklasifikasikan tiga faktor penyebab munculnya konflik, yaitu: ketergantungan kerja, perbedaan tujuan, dan perbedaan persepsi. Ketergantungan kerja terjadi ketika dua atau lebih kelompok organisasi bergantung satu sama lain untuk menyelesaikan tugas/pekerjaan. Kondisi ini dapat menjadi pemicu munculnya konflik. Organisasi yang tidak memiliki tujuan dan persepsi yang sama juga mempunyai potensi terjadinya konflik.

Rivai dan Sagala (2011) memandang bahwa konflik dapat disebabkan oleh adanya saling ketergantungan tugas, perbedaan tujuan dan prioritas, faktor birokrasi, kriteria penilaian prestasi yang tidak tepat, persaingan atas sumber daya yang langka dan sikap menang-kalah. Menurut Daft (2011), faktor yang mempengaruhi terciptanya konflik adalah persaingan untuk mendapatkan sumber daya, perbedaan tujuan yang ingin dicapai, dan gangguan komunikasi.

Nye (dalam Rakhmat, 2005) menyatakan ada lima sumber konflik dalam hubungan antarindividu, yaitu: (1) kompetisi, salah satu pihak berusaha mendapatkan sesuatu dengan cara mengorbankan pihak lain; (2) dominasi, salah satu pihak berusaha mengendalikan pihak lain; (3) kegagalan, masing-masing pihak berusaha menyalahkan pihak lain apabila tujuan bersama tidak tercapai; (4) provokasi, salah satu pihak terus melakukan sesuatu yang diketahui menyinggung perasaan pihak lain; dan (5) perbedaan nilai, kedua belah pihak tidak sepakat dengan nilai-nilai yang dianut. Bagi Khanaki (2010), konflik dapat disebabkan oleh miskin komunikasi, ketidakpuasan akibat gaya manajemen, keinginan akan kekuasaan, kepemimpinan yang tidak efektif dan ketidakterbukaan.

Konflik dapat dikategorikan dalam beberapa bentuk. Pickering (2001) mengklasifikasi empat jenis konflik: (1) Konflik diri, yaitu gangguan emosi yang terjadi dalam diri individu karena tuntutan untuk 
menyelesaikan suatu pekerjaan atau memenuhi suatu harapan sementara pengalaman, minat, tujuan dan tata nilai individu tidak dapat memenuhinya. Konflik diri menggambarkan perbedaan antara perkataan, keinginan, dan tindakan untuk mewujudkan tujuan. (2) Konflik antarindividu, yaitu konflik antara dua individu yang muncul karena perbedaan kebutuhan dasar psikologis yang meliputi keinginan untuk dihargai dan diperlakukan sebagai manusia, keinginan memegang kendali, keinginan memiliki harga diri yang tinggi, dan keinginan untuk konsisten. Setiap individu berupaya untuk memenuhi kebutuhan-kebutuhan tersebut. Kegagalan pemenuhan kebutuhan-kebutuhan itu mendorong individu bereaksi secara berbeda seperti membalas, menguasai, mengucilkan diri atau mengajak bekerja sama. Ketidakterpenuhi dapat memicu timbulnya konflik. (3) Konflik dalam kelompok. Munculnya konflik dalam kelompok disebabkan oleh perbedaan pendapat dan kepentingan para anggota. Masalah komunikasi yang kurang efektif dapat juga menimbulkan perbedaan pendapat yang dapat mengarah kepada konflik. (4) Konflik antarkelompok. Konflik antarkelompok terjadi dalam semua jenis organisasi. Konflik ini muncul adanya persaingan perbedaan tujuan dan nilai-nilai.

Rivai dan Sagala (2011) mengkategorikan enam jenis konflik, yaitu: (1) Konflik internal, terjadi ketika individu dihadapkan pada pilihan yang bertentangan atau tuntutan tugas yang melebihi kemampuannya. (2) Konflik antarindividu, muncul karena adanya perbedaan tentang isu tertentu, tindakan, dan tujuan dimana hasil bersama sangat menentukan. (3) Konflik antaranggota kelompok, timbul karena latar belakang keahlian yang berbeda atau berdasarkan tanggapan emosional terhadap suatu situasi. (4) Konflik antarkelompok, terjadi karena masing-masing kelompok ingin mengejar kepentingan kelompoknya. (5) Konflik intraperusahaan, meliputi empat jenis: (a) konflik vertikal, terjadi karena ketidaksepahaman antara manajer dengan bawahan dalam menyelesaikan tugas; (b) konflik horizontal, terjadi antara karyawan atau departemen yang memiliki hirarki yang sama dalam organisasi; (c) konflik lini-staf, terjadi karena perbedaan persepsi tentang keterlibatan staf dalam proses pengambilan keputusan; (d) konflik peran, terjadi karena seseorang memiliki lebih dari satu peran yang saling bertentangan. (6) Konflik antarperusahaan, terjadi karena saling ketergantungan terhadap pemasok, pelanggan, maupun distributor.

Konflik merupakan suatu fakta yang dapat terus terjadi dalam setiap bentuk organisasi (Huan \& Yazdanifard, 2012). Jehn (dalam Shih \& Susanto, 2010) menegaskan bahwa dampak konflik tidak dapat dihindari. Jehn (dalam Shih \& Susanto, 2010) berpendapat bahwa di satu pihak konflik dalam organisasi telah mengganggu rutinitas dan mengurangi produktivitas dan kepuasan, di pihak lain melalui konflik sebuah organisasi memiliki potensi untuk meningkatkan kualitasnya berkaitan dengan pengambilan keputusan, kreativitas dan prestasi. Huan dan Yazdanifard (2012) juga menekankan dampak negatif dan positif pengelolaan konflik. Apabila konflik tidak dikelola akan mempengaruhi kepuasan kerja dan loyalitas karyawan. Sebaliknya konflik berperan sebagai garis pembelajaran bagi semua organisasi, karena tanpa konflik sebuah organisasi tidak dapat berkembang.

Pickering (2001) beranggapan bahwa konflik memiliki pengaruh negatif dan positif terhadap individuindividu yang terkait. Beberapa dampak buruk konflik seperti produktivitas menurun, kepercayaan merosot, terbentuknya kubu-kubu, informasi dirahasiakan dan arus komunikasi berkurang, serta munculnya masalah moral. Adapun dampak positif konflik antara lain dapat meningkatkan motivasi, identifikasi masalah meningkat, ikatan kelompok lebih erat, penyesuaian diri pada kenyataan, pengetahuan/keterampilan meningkat, kreativitas meningkat, membantu upaya mencapai tujuan, mendorong pertumbuhan.

Johnson (dalam Supratiknya, 1995:94-96) menggambarkan manfaat positif konflik sebagai berikut: (1) konflik dapat menyadarkan individu bahwa ada persoalan yang perlu dipecahkan dalam hubungan antarpribadi, (2) konflik dapat menyadarkan dan mendorong individu untuk melakukan perubahanperubahan internal, (3) konflik dapat menumbuhkan dorongan internal untuk memecahkan persoalan yang selama ini tidak disadari, (4) konflik dapat menjadikan kehidupan lebih menarik, (5) perbedaan pendapat dapat membimbing ke arah tercapainya keputusan-keputusan bersama yang lebih matang dan bermutu, (6) konflik dapat menghilangkan ketegangan-ketegangan dalam hubungan interpersonal, (7) konflik dapat menyadarkan individu tentang identitas diri yang sesungguhnya, (8) konflik dapat menjadi sumber hiburan, (9) konflik dapat mempererat dan memperkaya hubungan.

Ivancevich, Konopaske \& Matteson (2007) juga berpandangan bahwa konflik tidak hanya membawa akibat negatif tetapi juga dapat menjadi instrumen perubahan atau inovasi. Ivancevich, Konopaske \& Matteson (2007) berpendapat bahwa terdapat konflik fungsional yang merupakan konfrontasi antarkelompok yang dapat meningkatkan dan menguntungkan kinerja organisasi dan konflik disfungsional yang mengacu pada konfrontasi atau interaksi antarkelompok yang membahayakan atau menghambat organisasi dalam mencapai tujuan. 
Konflik tidak dapat dihindari dalam hidup bersama; bahkan dapat dikatakan bahwa konflik merupakan bagian dari kehidupan manusia. Konflik merupakan suatu fakta yang harus dihadapi. Persoalan yang muncul adalah bagaimana mengelola konflik secara efektif. Upaya menjawab pertanyaan tersebut adalah kebutuhan akan manajemen konflik yang efektif. Brewer, Mitchell \& Weber (2002) menegaskan bahwa keterampilan mengelola konflik dipandang penting apabila individu dapat berfungsi secara efektif dalam berbagai level dalam organisasi.

Lipsky \& Seeber (dalam Aula \& Siira, 2010) menggunakan istilah sistem manajemen konflik untuk menggambarkan seperangkat kebijakan yang dirancang untuk mengelola konflik. Menurut Morberg (dalam Shih \& Susanto, 2010) gaya manajemen konflik merupakan pola perilaku tertentu yang cenderung digunakan individu dalam berhadapan dengan konflik. Womack (dalam Ma, 2007) memaparkan bahwa gaya manajemen konflik merupakan suatu intensi perilaku individu dalam menghadapi konflik. Menurut Wikipedia (dalam http://en.wikipedia.org/wiki/conflict_management) manajemen konflik mencakup cara individu meningkatkan aspek positif dan mengurangi aspek negatif konflik. Dengan kata lain, konflik perlu dikelola dengan baik. Rahim (dalam http://en.wikipedia.org/wiki/conflict_management) menegaskan bahwa pengelolaan konflik dilakukan untuk meningkatkan hasil belajar dan kelompok termasuk meningkatkan efektivitas atau kinerja dalam organisasi. Menurut Ross (dalam Herdiansyah, 2014) manajemen konflik merupakan langkah-langkah yang diambil untuk mengarahkan perselisihan ke arah hasil tertentu yang mungkin atau tidak mungkin menghasilkan suatu akhir berupa penyelesaian konflik dan mungkin atau tidak mungkin menghasilkan ketenangan, hal positif, kreatif, bermufakat, atau agresif. Manajemen konflik dapat melibatkan bantuan diri sendiri, kerjasama dalam memecahkan masalah.

Ada beberapa strategi untuk menangani konflik (Montes, Rodriguez, \& Serrano, 2012). Banyak ahli mengembangkan gaya managemen konflik dalam dua model, yaitu model yang menaruh perhatian pada diri sendiri dan orang lain. Kedua model ini memiliki keunikan yang menantang individu untuk memilih gaya yang berbeda dalam mengelola konflik (Ma, 2007). Thomas dan Thomas (2008, dalam Daft, 2010) menampilkan lima gaya penanganan konflik: gaya bersaing, gaya menghindar, gaya kompromi, gaya akomodasi, dan gaya kolaborasi. (1) Gaya bersaing, mencerminkan ketegasan individu untuk memenangkan keinginannya. Gaya ini digunakan efektif apabila situasi saat itu membutuhkan keputusan yang cepat dan kepentingan salah satu pihak lebih diutamakan. Situasi yang akan terjadi adalah terciptanya menang-kalah dimana pihak yang kalah akan merasa dirugikan dan dapat menjadi konflik yang berkepanjangan. (2) Gaya menghindar. Gaya ini tidak mencerminkan ketegasan individu dan cocok digunakan ketika persoalan bersifat sepele. Gaya ini efektif digunakan ketika tidak ada kesempatan untuk menang, persoalan yang dihadapi tidak penting, dibutuhkan banyak waktu untuk mengumpulkan informasi. Kelemahan gaya ini adalah melemparkan masalah ke orang lain, menarik diri dari situasi yang ada dan membiarkan orang lain menyelesaikannya, menunggu lama untuk mendapatkan jawaban dan tidak banyak memberi jawaban sehingga konflik akan terus berlanjut. (3) Gaya berkompromi, mencerminkan jalan tengah antara ketegasan dan kerja sama. Gaya ini cocok digunakan ketika tujuan kedua belah pihak sama-sama penting, ketika pihak lawan memiliki kekuatan setara, atau ketika orang-orang harus membuat solusi sementara dan bijaksana di bawah tekanan waktu. Dengan kata lain, gaya kompromi mengutamakan hubungan baik dan mengorbankan sebagian kepentingan diri untuk mendapatkan situasi yang menang-menang. (4) Gaya mengakomodasi, mencerminkan derajat kerjasama yang tinggi dan cocok digunakan ketika orang-orang menyadari bahwa mereka salah, ketika persoalan lebih berarti bagi orang lain daripada diri sendiri, ketika sedang membangun citra sosial untuk dijadikan modal dalam diskusi mendatang, dan ketika menjaga keselarasan yang penting. (5) Gaya berkolaborasi, mencerminkan tingkat ketegasan dan kerja sama tinggi. Gaya kolaborasi memungkinkan kedua pihak sama-sama menang. Gaya ini menyatukan langkah semua pihak pada upaya mencari pemecahan pada persoalan yang kompleks. Dengan kata lain, orang yang menggunakan gaya kolaborasi berupaya menciptakan situasi yang menang-menang dengan menjunjung tinggi kerja sama. Namun gaya ini tidak efektif digunakan apabila pihak terkait tidak memiliki niat untuk menyelesaikan masalah.

Johnson (dalam Supratiknya, 1995) menggolongkan lima gaya manajemen konflik: (1) Gaya kura-kura. Sama seperti kura-kura yang lebih senang menarik diri bersembunyi di balik tempurung badannya, individu menggunakan gaya ini cenderung menarik diri atau menghindar dari konflik. Upaya memecahkan konflik dipandang sia-sia. (2) Gaya ikan hiu. Individu yang menggunakan gaya ikan hiu berupaya memaksa lawannya untuk menerima solusi konflik yang ditawarkannya. Konflik harus dipecahkan dengan cara satu pihak menang dan pihak lainnya kalah. Prioritasnya ditekankan bukan pada hubungan dengan pihak lain, melainkan tercapainya tujuan pribadi. (3) Gaya kancil. Individu yang menggunakan gaya kancil mengutamakan hubungan dan kurang mementingkan tujuan pribadi. Individu dengan gaya ini beranggapan 
bahwa konflik harus didamaikan, bukan dipecahkan agar hubungan tidak menjadi rusak. (4) Gaya rubah. Bagaikan rubah yang senang mencari kompromi, individu dengan gaya ini berupaya kompromi agar tujuantujuan pribadi dan hubungan baik dapat dicapai. (5) Gaya burung hantu. Individu yang menggunakan gaya burung hantu mengutamakan tujuan-tujuan pribadi sekaligus hubungannya dengan pihak lain. Konflik merupakan masalah yang harus diselesaikan dan pemecahannya harus sejalan dengan tujuan pribadi maupun tujuan lawannya. Dengan kata lain, individu dengan gaya ini berusaha mencari penyelesaian yang memuaskan kedua pihak.

Rivai dan Sagala (2011) mengklasifikasi tiga metode dalam menyelesaikan konflik, yaitu: (1) Dominasi. Metode ini dilakukan dengan beberapa cara seperti kekerasan, penenangan, penghindaran, dan melalui aturan mayoritas. (2) Kompromi. Gaya ini mengacu pada penyelesaian konflik melalui jalan tengah yang dapat diterima oleh kedua pihak. Adapun bentuk-bentuk kompromi adalah pemisahan, perwasitan, kembali ke peraturan yang berlaku, dan penyuapan. (3) Pemecahan masalah integratif. Konflik diubah menjadi situasi pemecahan masalah bersama melalui teknik-teknik pemecahan masalah yang dilakukan melalui konsensus, konfrontasi, dan penggunaan tujuan-tujuan yang lebih tinggi.

\section{Metode}

Subjek penelitian adalah para seminaris kongregasi $\mathrm{X}$ yang sedang menjalani proses pembinaan menjadi imam berjumlah 44 orang. Rata-rata usia para seminaris adalah 22 tahun. Penelitian ini dilakukan di Malang. Peneliti melakukan penelitian deskriptif yang bertujuan untuk menggambarkan gaya manajemen konflik para seminaris. Penelitian ini memiliki satu variabel yaitu gaya manjemen konflik. Instrumen yang digunakan adalah skala penilaian gaya manajemen konflik yang dibuat oleh peneliti dengan menggunakan lima pilihan jawaban yaitu selalu (SL), sering (SR), kadang-kadang (KK), jarang (J), dan tidak pernah (TP). Instrumen gaya manajemen konflik sebanyak 50 pernyataan diperoleh 38 pernyataan yang valid dengan reliabilitas 0,909 .

\section{Hasil dan Pembahasan}

Instrumen penelitian gaya manajemen konflik terdiri atas lima komponen gaya, yaitu 1) gaya kompetisi, 2) gaya kolaborasi, 3) gaya kompromi, 4) gaya menghindar, dan 5) gaya akomodasi. Tabel 1 memaparkan mean dan standar deviasi gaya manajemen konflik para seminaris. Berdasarkan data statistik, diperoleh mean untuk gaya kompetisi sebesar 27.66, kolaborasi sebesar 36.95, kompromi sebesar 35.09, menghindar sebesar 34.18, dan akomodasi sebesar 37.00. Dari hasil skor rata-rata gaya manajemen konflik kita dapat melihat mean tertinggi pada gaya akomodasi sebesar 37.00 dan diikuti gaya kolaborasi (36.95), gaya kompromi (35.09), dan gaya menghindar (34.18). Mean terendah terdapat pada gaya kompetisi sebesar 27.00 .

Tabel 1. Hasil deskriptif statistik gaya manajemen konflik

\begin{tabular}{lcc}
\hline \multicolumn{1}{c}{ Gaya manajemen konflik } & Mean & Std. Deviation \\
\hline Gaya kompetisi & 27.66 & 4.983 \\
Gaya kolaborasi & 36.95 & 5.502 \\
Gaya kompromi & 35.09 & 5.842 \\
Gaya menghindar & 34.18 & 4.484 \\
Gaya akomodasi & 37.00 & 5.595 \\
\hline
\end{tabular}

Tabel 2 menjelaskan uji anova yang dilakukan untuk membandingkan gaya manajemen konflik. Berdasarkan uji anova (taraf signifikan 0.05) diperoleh perbedaan antara lima gaya secara signifikan karena $\mathrm{p}<0.05$.

Tabel 2. Hasil uji anova gaya manajemen konflik

\begin{tabular}{lrrrrr}
\hline Gaya & Sum of Squares & df & Mean Square & \multicolumn{1}{c}{ F } & Sig. \\
& 2596.109 & 4 & 649.027 & 23.072 & .000 \\
Between Groups & 6047.977 & 215 & 28.130 & & \\
Within Groups & 8644.086 & 219 & & & \\
Total & & & & & \\
\hline
\end{tabular}


Tabel 3 menggambarkan perbedaan pasangan gaya manajemen konflik. Secara keseluruhan hasil uji anova, terdapat perbedaan pasangan yang signifikan antara kelima gaya.

Tabel 3. Perbedaan pasangan gaya manajemen konflik

\begin{tabular}{cllcc}
\hline No & & Pasangan antara gaya & Signifikasi & Hasil \\
\hline $\mathbf{1}$ & Kompetisi & - Kolaborasi & 0.000 & signifikan \\
$\mathbf{2}$ & Kompetisi & - Kompromi & 0.000 & signifikan \\
$\mathbf{3}$ & Kompetisi & - Menghindar & 0.000 & signifikan \\
$\mathbf{4}$ & Kompetisi & - Akomodasi & 0.000 & signifikan \\
$\mathbf{5}$ & Kolaborasi & - Kompromi & 0.607 & non signifikan \\
$\mathbf{6}$ & Kolaborasi & - Menghindar & 0.202 & non signifikan \\
$\mathbf{7}$ & Kolaborasi & - Akomodasi & 1.000 & non signifikan \\
$\mathbf{8}$ & Kompromi & - Menghindar & 0.958 & non signifikan \\
$\mathbf{9}$ & Kompromi & - Akomodasi & 0.188 & non signifikan \\
$\mathbf{1 0}$ & Menghindar - Akomodasi & 0.188 & non signifikan \\
\hline
\end{tabular}

Berdasarkan hasil uji t pasca pada (tabel 3), diperoleh perbedaan yang signifikan antara gaya kompetisikolaborasi, kompetisi-kompromi, kompetisi-menghindar, dan kompetisi-akomodasi. Sedangkan perbedaan yang tidak signifikan adalah pasangan gaya kolaborasi-kompromi, kolaborasi-menghindar, kolaborasiakomodasi, kompromi-menghindar, kompromi-akomodasi, dan menghindar-akomodasi.

Secara keseluruhan, dapat disimpulkan bahwa para seminaris X memiliki kecenderungan atau preferensi untuk memilih gaya akomodasi (mean $=37.00)$ dan jarang menggunakan gaya kompetisi $($ mean $=27.66)$ dalam mengelola konflik.

Penelitian ini berfokus pada gaya manajemen konflik para seminaris, yaitu kompetisi, menghindar, kompromi, akomodasi, dan kolaborasi sebagaimana dikembangkan Thomas (dalam Daft, 2010). Manajemen konflik diperlukan dalam diri setiap individu, karena konflik merupakan fakta yang harus dihadapi setiap individu dalam hidup bersama. Penerapan gaya managemen konflik tidak dapat dilakukan secara efektif untuk semua kondisi, maka setiap individu perlu mengembangkan kemampuan menggunakan setiap gaya secara efektif sesuai dengan situasi. Manajemen konflik dipandang penting apabila individu dapat berfungsi secara efektif dalam berbagai level dalam organisasi (Brewer, Mitchell \& Weber, 2002).

Berdasarkan hasil penelitian, diperoleh bahwa gaya manajemen konflik yang cenderung digunakan para seminaris $\mathrm{X}$ adalah gaya akomodasi $(m e a n=37.00)$ dan jarang memakai gaya kompetisi $(m e a n=27.66)$. Berdasarkan uji anova (taraf signifikan 0.05) diperoleh perbedaan antara lima gaya secara signifikan karena $\mathrm{p}<0.05$. Keadaan ini dapat terjadi karena para seminaris $\mathrm{X}$ memahami pentingnya kerja sama dan keselarasan yang harus dibangun dalam hidup bersama. Unsur-unsur seperti pengorbanan, menjaga hubungan dengan orang lain, dan memperhatikan keinginan komunitas menjadi pilar utama dalam membangun sebuah komunitas yang sehat. Penelitian ini mendukung pandangan Thomas (dalam Daft, 2010) yang menggambarkan bahwa individu yang memilih gaya akomodasi adalah individu yang mencerminkan derajat kerjasama yang tinggi dan menjaga keselarasan dalam hubungan. Contoh pernyataan gaya akomodasi: "saya menenangkan perasaan orang lain dan berupaya menjaga hubungan, saya mengorbankan keinginan saya untuk memenuhi keinginan orang lain, saya berusaha tidak menyakiti perasaan orang lain dalam penyelesaian masalah, saya mempertimbangkan keinginan orang lain dalam penyelesaian konflik." Hasil penelitian ini mendukung penelitian yang dilakukan Cornille et.all (1999) mengenai gaya manajemen konfik para guru dengan mitra kerja dan orangtua murid di Florida, Amerika Serikat. Hasil penelitian Cornille et.all (1999) menunjukkan bahwa dalam mengelola konflik, para guru lebih cenderung menggunakan gaya akomodasi daripada gaya menghindar. Faktor pendidikan membantu para guru menentukan gaya konflik dengan lebih baik yang cocok dengan situasi. Hasil penelitian ini berbeda dengan penelitian sebelumnya yang menunjukkan bahwa strategi manajemen konflik yang paling sering digunakan oleh perawat dan dokter pada saat berhadapan dengan konflik adalah menghindar (Basogul \& Ozgur, 2016; Dahshan \& Keshk, 2014; Johansen \& Cadmus, 2016; Kaitelidou et al., 2012; Lahana et al., 2019; Moisoglou et al., 2014). Hasil penelitian ini juga berbeda dengan penelitian Hasibuan (2016) yang menunjukkan bahwa mahasiswa perantau dari luar Pulau Jawa lebih cenderung menggunakan conflict approach avoidance maupun penelitian Ghavifekr, Nair, dan Ibrahim (2019) yang menyatakan bahwa 
pendekatan kolaborasi dan kompromi merupakan strategi yang digunakan oleh pemimpin sekolah, asisten senior, dan para guru ketika menghadapi situasi konflik.

\section{Kesimpulan}

Berdasarkan kajian teoretis dan hasil penelitian disimpulkan: pertama, konflik merupakan fakta yang tidak dapat dihindari oleh setiap individu dalam hidup bersama. Konflik perlu dikelola dengan baik agar dapat memperkuat hubungan interpersonal dan meningkatkan kepercayaan serta kepuasan hidup. Manajemen konflik yang tidak efektif akan memunculkan konflik baru berikutnya. Kegagalan dalam mengelola konflik tidak hanya menghambat pencapaian tujuan hidup bersama, tetapi juga merusak dinamika hubungan antarpribadi. Kedua, terdapat lima gaya manajemen konflik yang tidak dapat diterapkan secara efektif untuk semua kondisi. Individu perlu mengembangkan kemampuan menggunakan setiap gaya secara efektif sesuai dengan situasi. Ketiga, hasil penelitian menunjukkan bahwa gaya manajemen konflik yang cenderung atau menjadi prioritas untuk digunakan para seminaris $\mathrm{X}$ adalah gaya akomodasi (mean=37.00). Para seminaris $X$ jarang menggunakan gaya kompetisi (mean=27.66) dalam mengelola konflik. Berdasarkan uji anova (taraf signifikan 0.05) diperoleh perbedaan antara lima gaya secara signifikan karena $\mathrm{p}<0.05$. Bagi para seminaris, disarankan untuk mendalami gaya manajemen konflik yang cocok dalam menghadapi situasi konflik. Upaya pendalamannya dapat berupa mengikuti kegiatan pelatihan/seminar tentang pengelolaan konflik. Upaya kedua adalah dengan melakukan konseling individual maupun kelompok dalam mengembangkan gaya manajemen konflik yang efektif.

\section{Referensi}

Aula, P. \& Siira, K. (2010). "Organizational communication and conflict management systems a social complexity approach". Nordicom Review. 31 (1), 125-141.

Basogul, C., \& Ozgur, G. (2016). "Role of emotional intelligence in conflict management strategies of nurses". Asian Nursing Research. XXX, 1-6.

Beitler, L. A., Machowski, S., Johnson, S., \& Zapf, D. (2016). "Conflict management and age in service professions". International Journal of Conflict Management. 27 (3), 302-330.

Brewer, N. Mitchell, P. \& Weber, N. (2002). "Gender role, organizational status, and conflict management styles". The International Journal of Conflict Management. 13 (1). 78-94.

Chan, K. W. Huang, X. \& Ng. P. M. (2008). "Managers' conflict management styles and employee attitudinal outcomes: the mediating role of trust". Asia Pacific J Manage. (25), 277-295.

Chung-Yan, G. A. \& Moeller, C. (2010). "The psychosocial costs of conflict management styles". International Journal of Conflict Management.21 (4), 382-399.

Cornille, T. A., Pestle, R. E., \& Vanwy, R. W. (1999). "Teachers' conflict management styles with peers and students' parents". International Journal of Conflict Management. 10 (1), 69-79.

Daft, R. L. (2010). Era Baru Manajemen. Jakarta: Penerbit Salemba Empat.

Dahshan, M. E. A. E., \& Keshk, L. I. (2014). "Managers' conflict management styles and its effect on staff nurses' turnover intention at Shebin El Kom Hospitals, Menoufiya Governorate". World Journal of Medical Sciences. 11 (1), 132-143.

Darling, J. R. \& Walker, W. E. (2001). "Effective conflict management: Use of the behavioral style model". Leadership \& Organization Development Journal. 22 (5/6), 230-242.

Desivilya, H. S., \& Eizen, D. (2005). "Conflict management in work teams: the role of social self-efficacy and group identification". International Journal of Conflict Management.16 (2), 183-208.

Ghavifekr, S., Nair, A., \& Ibrahim, M. S. (2019). "Practising conflict management strategies in Primary Schools: A Malaysian scenario". Global Business and Management Research: An International Journal. 11 (1). 355-366.

Gross, M. A., Hogler, R., \& Henle, C. A. (2013). "Process, people, and conflict management in organizations: A viewpoint based on Weber's formal and substantive rationality". International Journal of Conflict Management. 24 (1), 90-103.

Hasibuan, A. A. (2016). "Strategi manajemen konflik antarpribadi antarbudaya pada mahasiswa perantau luar pulau Jawa di Kota Semarang". Intuisi: Jurnal Ilmiah Psikologi. 8 (2).

Herdiansyah, J. (2014). "Manajemen konflik dalam sebuah organisasi". Jurnal STIE Semarang. 6 (1), 28-41.

Huan, L. I. \& Yazdanifard, R. (2012). "The difference of conflict management styles and conflict resolution in workplace". Business \& Enterpreneurship Journal. 1 (1). 141-155.

Hendricks, W. (2006). Bagaimana Mengelola Konflik. Jakarta: Bumi Aksara. 
Ivancevich, J. M, Konopaske, R, Matteson, M. T. (2007). Perilaku Dan Manajemen Organisasi. Jakarta: Erlangga.

Johansen, M. L., \& Cadmus, E. (2016). "Conflict management style, supportive work environments and the experience of work stress in emergency nurses". Journal of Nursing Management. 24, 211-218.

Kaitelidou, D., Kontogianni, A., Galanis, P., Siskou, O., Mallidou, A., Pavlakis, A., Kostagiolas, P., Theodorou, M., \& Liaropoulos, L. (2012). "Conflict management and job satisfaction in paediatric hospitals in Greece". Journal of Nursing Management. 20, 571-578.

Kashanah, P. (2014). "Meningkatkan kemampuan manajemen konflik melalui konseling kelompok". Psikopedagogia. 3 (2), 68-78.

Khan, K., Hussainy, S. K., \& Iqbal, Y. (2016). "Causes, effects, and remedies in conflik management". The South East Asian Journal of Management. 10 (2), 152-172.

Khanaki, H. \& Hassanzadeh, N. (2010). "Conflict management styles: the Iranian general preference compared to the Swedish". International Journal of Innovation, Management and Technology. 1 (4). 419426.

Kim, T. Y., Wang, C., Kondo, M. \& Kim, T. H. (2007). "Conflict management styles: the differences among the Chinese, Japanese and Koreans". International Journal of Conflict Management. 18 (1), 23-41.

Lahana, E., Tsaras, K., Kalaitzidou, A., Galanis, P., Kaitelidou, D., \& Sarafis, P. (2019). "Conflicts management in public sector nursing". International Journal of Healthcare Management. 12 (1), 33-39.

Luthans, F. (2011). Organizational Behavior: An Evidence-Based Approach. New York, NY: Mcgraw-Hill/Irwin.

$\mathrm{Ma}, \mathrm{Z}$. (2007). "Conflict management styles as indicators of behavioral pattern in business negotiation". International Journal of Conflict Management. 18 (3), 260-279.

Mardianto, A., Koentjoro, \& Purnamaningsih, E. H. (200). "Penggunaan manajemen konflik ditinjau dari status keikutsertaan dalam mengikuti kegiatan pencinta alam di Universitas Gadjah Mada Yogyakarta". Jurnal Psikologi. 2, 111-119.

Marquis, B. L., \& Huston, C. J. (2012). Leadership roles and management fuction in nursing: Theory and application. Philadelphia: Lippincott Williams \& Wilkins.

Mullins, L. J. (2005). Management and organisational behaviour. Harlow Essex, England: Pearson Education Limited.

Moisoglou, I., Panagiotis, P., Galanis, P., Siskou, O., Maniadakis, N., \& Kaitelidou, D. (2014). "Conflict management in a Greek Public Hospital: Collaboration or avoidance?" International Journal of Caring Sciences. 7 (1), 75-82.

Montes, C., Rodriguez, D., \& Serrano, G. (2012). "Affective choice of conflict management styles". International Journal of Conflict Management. 23 (1), 6-18.

Pickering, P. (2001). Kiat Menangani Konflik. Jakarta: Erlangga.

Rahim, M. A. (2002). Conflict management. Retrieved October 10, 2012, from http://en.wikipedia.org/wiki/Conflict_management.

Rakhmat, J. (2005). Psikologi Komunikasi. Bandung: Remaja Rosdakarya.

Rivai, V. \& Sagala, E. J. (2011). Manajemen Sumber Daya Manusia untuk Perusahaan: Dari Teori ke Praktik. Jakarta: Rajawali Press.

Robbins, S. P. \& Judge, T. A. (2013). Organizational Behavior: Global Edition. Boston, Columbus: Pearson Education Limited.

Robbins, S. P. \& Judge, T. A. (2018). Essentials of Organizational Behaviour. Don Mills, Ontario: Pearson Canada Inc.

Shih, H. A. \& Susanto, E. (2010). "Conflict management styles, emotional intelligence, and job performance in public organizations". International Journal of Conflict Management.21 (2), 147-168.

Supratiknya, A. (1995). Komunikasi Antarpribadi, Tinjauan Psikologis. Yogyakarta: Kanisius.

Sutikno, T. A. (2008). "Pendekatan manajemen konflik pada lembaga Pendidikan". TEKNO: Jurnal Teknologi dan Kejuruan. 10 (2), 65-73.

Thomas, K. W. \& Thomas, G. F. (2008). "Conflict styles of men and women at six organizational leves". International Journal of Conflict Management.19 (2), 148-166.

Tubbs, L. S. \& Moss, S. (2008). Human Communication: Principles and Contexts. Europe: McGraw-Hill.

Wahyudi. (2011). Manajemen Konflik dalam Organisasi. Bandung: Alfabeta.

Wartini, S. (2015). "Strategi manajemen konflik sebagai upaya meningkatkan kinerja teamwork tenaga kependidikan". Jurnal Manajemen dan Organisasi. 6 (1), $64-73$.

Wikipedia. Konflik. Retrieved October 10, 2012, from http://id.wikipedia.org/wiki/Konflik. 
Wijayati, D. T. (2009). "Model konseptual manajemen konflik dalam organisasi (sebuah kajian)". BISMA: Jurnal Bisnis dan Manajemen. 1 (2), 148-157.

Wirawan. (2013). Konflik dan Manajemen Konflik (Konflik Perubahan dan Pengembangan). Bandung: Mandar Maju. 